\title{
Geochemical Climofunctions from North American Soils and Application to Paleosols across the Eocene-Oligocene Boundary in Oregon
}

\author{
Nathan D. Sheldon, Gregory J. Retallack, and Satoshi Tanaka ${ }^{1}$ \\ Department of Geological Sciences, University of Oregon, Eugene, Oregon 97403, U.S.A. \\ (e-mail: nsheldon@darkwing.uoregon.edu)
}

\begin{abstract}
A B S T R A C T
The degree of chemical weathering in soils increases with mean annual precipitation $(P ; \mathrm{mm})$ and mean annual temperature $\left(T ;{ }^{\circ} \mathrm{C}\right)$. We have quantified these relationships using a database of major-element chemical analyses of 126 North American soils. The most robust relationship found was between $P$ and the chemical index of alteration without potash (CIA-K): $P=221.12 e^{0.0197(\text { IIA-K) }}$ with $R^{2}=0.72$. Another strong relationship was found between $P$ and the molecular ratio of bases/alumina $(B): P=-259.34 \ln (B)+759.05$ with $R^{2}=0.66$. A Mollisol-specific relationship was found relating $P$ to the molar ratio of calcium to aluminum $(C)$ as follows: $P=-130.93 \ln (C)+467.4$ with $R^{2}=0.59$. Relationships between weathering ratios and $T$ are less robust, but a potentially useful one was found between $T$ and the molecular ratio of potash and soda to alumina $(S)$ where $T=-18.516(S)+17.298$ with $R^{2}=$ 0.37. Our data also showed that most Alfisols can be distinguished from Ultisols by a molecular weathering ratio of bases/alumina of $<0.5$ or by a chemical index of alteration without potassium $<80$. Application of these data to a sequence of Eocene and Oligocene paleosols from central Oregon yielded refined paleoprecipitation and paleotemperature estimates consistent with those from other pedogenic and paleobotanical transfer functions for paleoclimate.
\end{abstract}

\section{Introduction}

The degree of chemical weathering in soils by hydrolysis increases with available precipitation and temperature. Both water and warmth serve to accelerate the depletion of alkali and alkaline earth elements $(\mathrm{Ca}, \mathrm{Mg}, \mathrm{Na}, \mathrm{K})$ at the expense of refractory elements such as aluminum (Al). Here we quantify these relationships using geochemical analyses previously published in a national survey of North American soils (table 1; available free of charge upon request from the Journal of Geology's Data Repository; Marbut 1935). These data are not a promising source of climofunctions, as defined by Jenny (1941), because the soils vary enormously in time for formation and parent material. They also vary greatly in local vegetation, the effects of which are difficult to disentangle from vegetation and climate at a continent-wide scale (table 2; available free of charge upon request from the 2002

Manuscript received September 18, 2001; accepted April 30,

${ }^{1}$ Department of Earth Sciences, Kyoto University of Education, Kyoto 612-8522, Japan.
Journal of Geology's Data Repository). Despite this, useful climofunctions have emerged from these data, presumably because of constraints on other soil-forming factors. Most of the soils were rejuvenated by late Quaternary glacial loess or till and are friable, nonrocky soils of plains and extensive terraces of agricultural promise. Furthermore, all the geochemical analyses were done using the same standards and in the same laboratories. Soon after C. F. Marbut's death and replacement as head of the Soil Survey Division by C. E. Kellogg in 1935, analyses of the cation exchange capacity became more popular than bulk geochemical analysis in soil survey and soil classification (Arnold 1994). For example, the boundary between Alfisols and Ultisols, which both have subsurface clay skins and clay accumulation, is defined in part by a base saturation of $35 \%$ or more for Alfisols and less for Ultisols (Soil Survey Staff 1998). Because this feature of soils also is related to degree of weathering and climatic variables such as precipitation and temperature, we

[The Journal of Geology, 2002, volume 110, p. 687-696] @ 2002 by The University of Chicago. All rights reserved. 0022-1376/2002/11006-0004\$15.00 
have identified bulk geochemical criteria for this important taxonomic division.

Much of the motivation for this study comes from the search for climofunctions and taxonomic criteria suitable for use in the paleoenvironmental interpretation of paleosols (Retallack 1994, 1997, $2001 b$ ). Base saturation and cation exchange capacity of soils are not preserved in paleosols and are substantially altered soon after burial (Retallack 1991), but the bulk chemical composition of paleosols appears to be robust in the face of diagenetic (Mora et al. 1998) and even metamorphic alteration (Barrientos and Selverstone 1987). In the second part of this study, we test the identified climofunctions using chemical data from paleosols (Retallack et al. 2000). Although the climofunctions found lack precision, we judge them worthwhile to the extent that they demonstrate significant paleoclimatic trends that are supported by other proxy paleoclimatic evidence from paleosols (Retallack 1994; Retallack et al. 2000) and fossil plants (Manchester 1994; Meyer and Manchester 1997).

\section{Material and Methods}

All the chemical analyses of soils used were published by Marbut (1935). He published data obtained from different portions of the soils /colloid vs. whole soill. We used the portion of the data obtained from whole soil analyses after the soil had been oven dried at $110^{\circ} \mathrm{C}$. Because of burial compaction (e.g., Sheldon and Retallack 2001) and diagenesis, it is difficult to impossible to separate only the colloidal fraction of a paleosol. We reformulated the data as molecular weathering ratios by dividing each weight percent by the molecular weight of the oxide in question, giving us relative abundance on an atomic stoichiometric basis rather than on the basis of weights (Retallack 1997, 2001b). Climatic data were drawn from stations within 20 miles of each of the soil sites (Hare and Thomas 1974; Ruffner 1980). For each site, we also determined the current soil series and profile name as well as its identification in Keys to Soil Taxonomy (Soil Survey Staff 1998) of the United States Soil Conservation Service by consulting a wide array of published soil surveys (tables 1,2). Table 1 consists of soil classifications and climatic data. Table 2 lists vegetative cover, topography, parent material, and estimated formation time for each of the soils. We scanned and plotted this large database using computer spreadsheets to identify any significant relationships between chemical and climatic data in a much more comprehensive manner than in our previous attempts to analyze these same data (Tegge 1986; Ready and Retallack 1995).

\section{Constraints on Climofunctions for North American Soils}

The accuracy of climofunctions depends on a wellconstrained climosequence, defined by Jenny (1941) as a set of soils varying in climate but showing little variation in other soil-forming variables such as vegetation, soil animals, topographic relief, parent material, and time for formation. A well-constrained climofunction would have to be confined to a limited area in order to avoid changes in vegetation that accompany climatic variation, but such geographic restriction also limits its usefulness for application to paleosols. An example is Jenny's (1941) classic climofunction of mean annual precipitation and depth to calcic horizon in grassland soils on postglacial loess of the North American central Great Plains. A comparably accurate climofunction between precipitation and depth to calcic horizon can be obtained if the choice of soils is relaxed to those with nodular carbonate (not wispy or tabular) on friable, loamy to gravelly, sedimentary parent materials of varied chemical composition in climates ranging from the Tropics to the Poles (Retallack 1994). However, the relationship rapidly falls apart when expanded to soils with tabular carbonate on hillslopes prone to erosion and on hard bedrock parent materials (Royer 1999; Retallack 2000). This is regrettable because a relationship between depth to calcic horizon and precipitation for hillslope and bedrock soils would be useful, and failure of the relationship for steeply sloping soils limits its universal application.

From this perspective, Marbut's (1935) selection of soils used here is not a well-constrained climosequence. It ranges over many soil-forming variables (table 2), so that any statistically significant relationship emerging should be of widespread applicability. The database is best constrained for topographic relief and parent material texture because emphasis on widespread and agriculturally important soils focused attention on well-drained, loamy soils without abundant gravel or shallow bedrock, on rolling plains and extensive terraces. Parent materials vary considerably from volcanic ash to basaltic-andesitic gravel and deeply weathered granite, but this variation is not as wide as it could have been because of the widespread influence of calcareous postglacial loess in most parts of the continent. Vegetation of the soils includes desert scrub, sagebrush grasslands, cool temperate grasslands, broadleaf woodlands, and 
conifer forests. Time for formation also varies from land surfaces only a few thousand years old on desert playas and coastal sand plains to surfaces millions of years old on bedrock terraces. Although the variation in time for formation, parent material, and vegetation gives our climofunctions potentially widespread application, we do not expect them to perform beyond the parameters of the climosequence. Australia, for example, lacks active volcanoes and has large flat areas of geochemically mature soils and rocks quite different from North America (Ollier and Pain 1996).

We tried different horizons, depth functions, and parent-corrected formulations of the data as well as a variety of molecular weathering ratios and found the best climofunctions emerged from the chemical composition of the subsurface ( $\mathrm{Bt}$ or $\mathrm{Bw}$ ) horizon. Molecular weathering ratios for surface horizons, ratios between horizons, and between key variables as a function of depth did not perform as well in our systematic search for statistically significant relationships. In addition to new relationships, we reassessed previous formulations including the chemical index of alteration (Nesbitt and Young 1982; Maynard 1992) and the molecular ratio of bases to alumina (Retallack 1997, 2001b).

\section{Climofunctions}

Nesbitt and Young (1982) proposed the chemical index of alteration (CIA) as a measurement of the degree of rock weathering. It is calculated by taking the molar ratio of $\mathrm{Al}_{2} \mathrm{O}_{3}$ to $\mathrm{Al}_{2} \mathrm{O}_{3}+\mathrm{CaO}+$ $\mathrm{Na}_{2} \mathrm{O}+\mathrm{K}_{2} \mathrm{O}$ (alumina, lime, soda, and potash) and multiplying it by 100 . Alkalies are found predominantly in feldspars and micas, so the CIA is a measurement of the breakdown of those types of minerals. A stoichiometric albite has a CIA value of 50, and a stoichiometric anorthite has a CIA value of 33. Maynard (1992) suggested calculating the CIA without potash (CIA-K) to control for the effects of potassium metasomatism in paleosols. For application to paleosols, we have chosen to use CIA-K values in place of CIA values. In both Maynard's (1992) original data and in the Marbut (1935) data, there is an extremely strong correlation $\left(R^{2}=0.97\right)$ between CIA and CIA-K values. Maynard (1992) also suggested an index of the weathering of $\mathrm{Mg}$-bearing minerals calculated by multiplying the molar ratio of $\mathrm{Al}_{2} \mathrm{O}_{3}$ to $\mathrm{Al}_{2} \mathrm{O}_{3}+\mathrm{MgO}$ by 100.

Retallack $(1997,2001 b)$ has suggested that the molecular ratio of $\mathrm{MgO}+\mathrm{CaO}+\mathrm{Na}_{2} \mathrm{O}+\mathrm{K}_{2} \mathrm{O}$ to $\mathrm{Al}_{2} \mathrm{O}_{3}$ calculated from oxides is an effective measurement of the degree of weathering because bases are the primary cations lost during weathering. One potential disadvantage of this approach is that $\mathrm{Mg}$ is generally hosted in different minerals than $\mathrm{Ca}$, $\mathrm{Na}$, and $\mathrm{K}$ (Maynard 1992). However, it is a more comprehensive measurement of base loss during weathering.

Among our various trials, the most robust relationship found was between mean annual precipitation $(P ; \mathrm{mm})$ and the chemical index of alteration without $\mathrm{K}(\mathrm{CIA}-\mathrm{K})$ :

$$
P=221 e^{0.0197(\text { CIA-K) }},
$$

which has reasonable accuracy $\left(R^{2}=0.72\right)$. Alternatively, it can be related linearly by

$$
P=14.265(\mathrm{CIA}-\mathrm{K})-37.632
$$

with slightly higher accuracy $\left(R^{2}=0.73\right)$. The results obtained by these two fits are broadly similar (fig. 1), but the exponential fit is favored for theoretical reasons because it comes closer to capturing the asymptote at CIA-K $=100$ (i.e., kaolinite). This relationship reflects higher precipitation leading to more intense chemical weathering, which preferentially removes the alkali and alkaline earth elements while leaving refractory elements such as aluminum in place. Low CIA-K values occur in soils with low $P$ due to the accumulation of $\mathrm{Ca}$ and $\mathrm{Mg}$ in Bk horizons or the accumulation of $\mathrm{Ca}$ and $\mathrm{Na}$ in evaporite minerals. These base cations are not readily removed when there is little chemical weathering. The equation relating CIA-K to precipitation is useful over a precipitation range of 200-1600 mm/yr using the exponential fit (eq. [1]). A CIA-K value of 100 yields a precipitation esti-

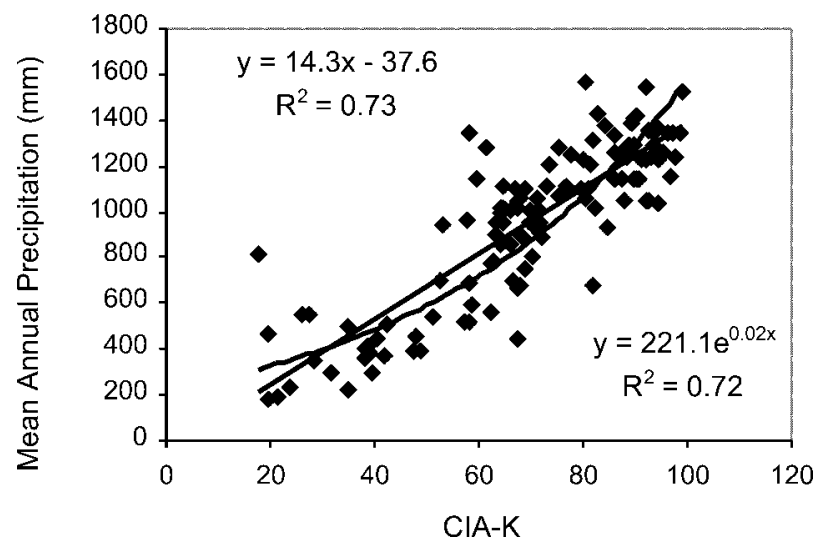

Figure 1. Relationship between mean annual precipitation and CIA-K in a national survey of North American soils (Marbut 1935). 


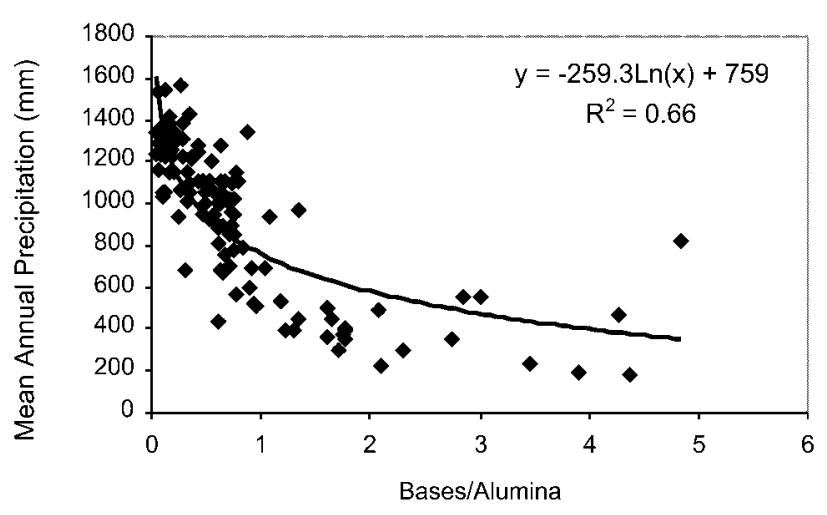

Figure 2. Relationship between mean annual precipitation and the molecular ratio of $\mathrm{CaO}+\mathrm{MgO}+\mathrm{Na}_{2} \mathrm{O}+$ $\mathrm{K}_{2} \mathrm{O}$ to $\mathrm{Al}_{2} \mathrm{O}_{3}$ in a national survey of North American soils (Marbut 1935).

mate of $1585 \mathrm{~mm}$ and represents a soil that was composed largely of kaolinite and refractory minerals such as $\mathrm{Fe}$ and $\mathrm{Al}$ sesquioxides as in an Oxisol or lateritic soil. This relationship is not usefully applied to soils with near-surface carbonate or evaporite minerals like those found in desert soils, nor is it useful for soils that are thick and composed only of highly weathered minerals such as kaolinite, gibbsite, and boehmite (as in a laterite). This relationship also does not apply to swamps, bogs, and other waterlogged ground, eolian dunes, ground freshly disturbed by human activities, or hillslope and montane soils.

While the Mg-index of Maynard (1992) shows a comparable correlation with $P$, we favor the molecular ratio of bases to alumina because low- or high-Mg soils (e.g., basalt-parent soils) give unlikely or impossible paleoprecipitation estimates. The molar ratio of bases to alumina $(B)$ is also related to $P$ with comparable accuracy $\left(R^{2}=0.66\right)$ to CIA$\mathrm{K}$ as follows:

$$
P=-259.34 \ln (B)+759.05 \text {. }
$$

This relationship is also useful for $200-1600 \mathrm{~mm} /$ yr $P$ (fig. 2). While it could theoretically predict higher precipitation values, the analytical uncertainties in analyses of such low amounts of weatherable bases make it unsuitable for precipitation in excess of $1600 \mathrm{~mm} / \mathrm{yr}$. As for CIA-K (eqq. [1], [2]), this relationship is not useful for desert soils, waterlogged soils, disturbed soils, or soils forming on significant topographic relief.

Mollisols are grassland soils that are unknown in the geologic record before the Cenozoic (Retallack 2001a). Plotting of Mollisol data alone yielded a potentially useful relationship between the molar ratio of lime to alumina $(C)$ and $P$ :

$$
P=-130.93 \ln (C)+467.4 \text {, }
$$

where $R^{2}=0.59$ (fig. 3). In wetter Mollisols, Ca can be readily weathered. In drier settings, $\mathrm{Ca}$ is less readily leached and accumulates in $\mathrm{Bk}$ horizons giving higher $\mathrm{CaO}$ to $\mathrm{Al}_{2} \mathrm{O}_{3}$ ratios.

Attempts to relate molecular weathering ratios to mean annual temperature $\left(T ;{ }^{\circ} \mathrm{C}\right)$ yield less robust relationships $\left(R^{2}<0.5\right)$. One potentially useful relationship (fig. 4) was found between $T$ and molecular ratio of $\mathrm{Na}_{2} \mathrm{O}$ and $\mathrm{K}_{2} \mathrm{O}$ to $\mathrm{Al}_{2} \mathrm{O}_{3}(S)$ :

$$
T=-18.516(S)+17.298,
$$

again with reasonable accuracy $\left(R^{2}=0.37\right)$. In spite of the low $R^{2}$ value, this relationship, like those for precipitation, is significant at the $99.9 \%$ level $(t=8.5154, F=72.58)$. The useful $T$ range for this relationship is approximately $2^{\circ}-20^{\circ} \mathrm{C}$. At higher temperatures, most $\mathrm{Na}$ and $\mathrm{K}$ are leached nearly completely. Many desert soils show up-profile augmentation of both $\mathrm{Na}$ (in evaporite minerals) and $\mathrm{K}$ (K-bearing minerals are less readily weathered than Ca- or Mg-bearing minerals) and have low T's because of extreme seasonality (Retallack 2001b). A logarithmic fit to the data is comparably accurate and better predicts high temperatures but fails to predict lower temperatures and would only be useful for $8^{\circ}-22^{\circ} \mathrm{C}$. This relationship should not be used for frigid soils with frost heave structures, patterned ground, and other features of polar soils (Washburn 1980; Bockheim 1997), nor for deeply weathered thick kaolinitic soils of tropical regions (Ollier and Pain 1996). As for the other climofunc-

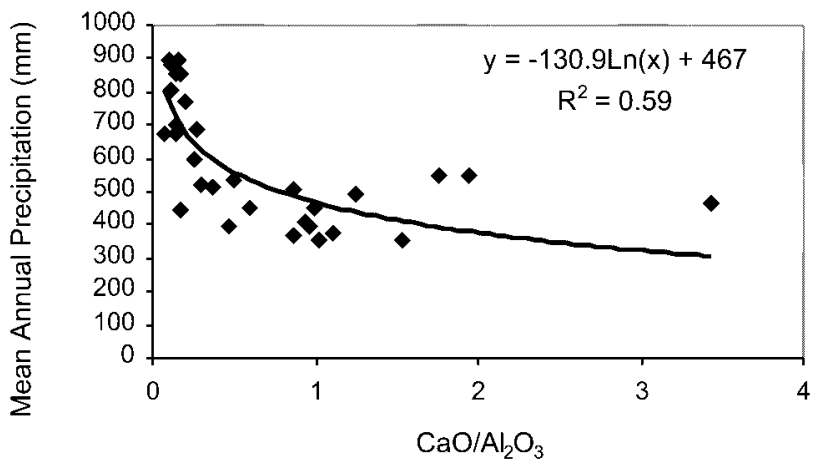

Figure 3. Relationship between mean annual precipitation and the molecular ratio of $\mathrm{CaO}$ to $\mathrm{Al}_{2} \mathrm{O}_{3}$ of Mollisols in a national survey of North American soils (Marbut 1935). 
tions above, this one also should not be used for swampy, eolian, disturbed, or hillslope soils.

\section{Geochemical Criteria for North American Soil Classification}

While readily identifiable and diagnostic features are often preserved in paleosols, distinguishing among some modern soil orders can be difficult. For this reason, we looked for molecular weathering ratios that are able to distinguish among soil orders. Table 3 compares Alfisols, Ultisols, and Mollisols. While identification of a Mollisol requires a mollic epipedon, table 3 demonstrates that they are also chemically distinct from the two forest soil orders. This comparison also shows that while one of the primary differences between modern Alfisols and Ultisols is landscape stability (i.e., formation time between disturbances), mean annual temperature and mean annual precipitation conditions are also significantly different. In North America both precipitation and temperature decrease in the order Ultisol $>$ Alfisol $>$ Mollisol. Further, there is no overlap in CIA-K values of Alfisols and Ultisols within 1 SD of their respective means and only a slight overlap between base to alumina ratio means, plus (or minus) $1 \mathrm{SD}$. This suggests that both CIA-K and bases/alumina molecular ratios are useful in distinguishing Alfisols from Ultisols. Our data show that most Ultisols, unlike Alfisols, typically have a molecular weathering ratio of bases/alumina of $<0.5$. This corresponds to a molar ratio of alumina/bases of $>2$, often much greater for Ultisols and Oxisols (Retallack 1997). The most prominent exceptions are Alfisols on limestone in Tennessee (tables 1,$2 ; \# 18$ ) and granite in Oregon (\#126) and an Ultisol on glauconitic marine sand in coastal Maryland (\#12). In each case, induration or unusually mafic parent materials explain the anomaly because these can limit both vegetation and weathering (Retallack 2001b).

Both CIA-K of $>80$ and the molecular ratio of bases/alumina of 0.5 can be considered proxies for the official criterion of $35 \%$ base saturation used in soil taxonomy to divide Alfisols with higher base saturation from Ultisols with lower values (Soil Survey Staff 1998). The relationship between base saturation and rainfall was examined for soils of the North American Great Plains by Jenny (1941), who found that it increased from a minimum in soils at $300 \mathrm{~mm}$ mean annual precipitation to a maximum in soils at $660 \mathrm{~mm}$ and then declined toward higher rainfalls. Scott (1962) produced a comparable curve for tropical Kenya, where because of much higher evapotranspiration, cation

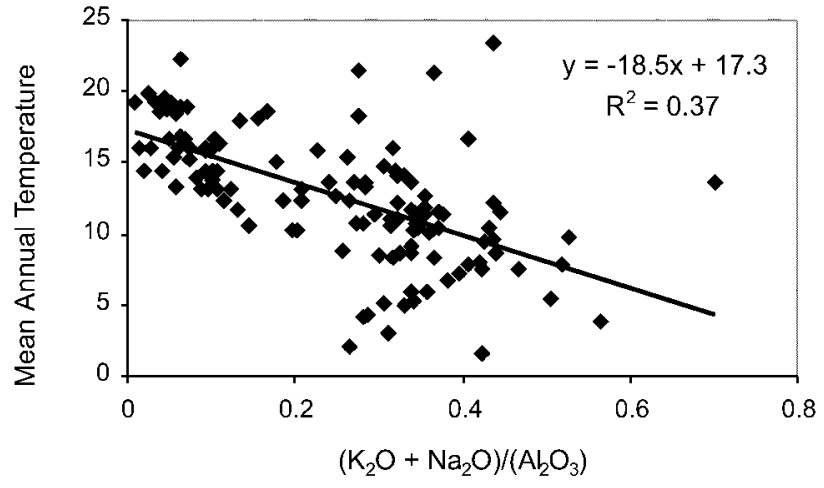

Figure 4. Relationship between mean annual temperature and molecular weathering ratio of $\mathrm{K}_{2} \mathrm{O}+\mathrm{Na}_{2} \mathrm{O}$ to $\mathrm{Al}_{2} \mathrm{O}_{3}$ in a national survey of North American soils (Marbut 1935).

exchange capacity of soils peaked at a mean annual precipitation of $1170 \mathrm{~mm}$. Comparable relationships over a shorter range of precipitation have also been found in Natal (Donkin and Fey 1993) and New Zealand (McIntosh et al. 1983). In both North America and Kenya, cation exchange capacity is limited in aridland soils because of their lack of clay that provides most sites of ionic exchange in soils. Cation exchange is also limited in soils of very humid climates because their clays have a low content of alkali and alkaline earth cations as a result of long and profound weathering (Folkoff 1987). Our curve of base depletion with rainfall (fig. 2 ) is a proxy for the downward slope of this curve at high rainfalls but not the upward slope at low rainfalls. Using our preferred climofunction (fig. 1), we reach the critical CIA-K of 80 at a rainfall of $1069 \mathrm{~mm}$. The isohyet boundary between Alfisols and Ultisols in the southeastern United States is close to $1200 \mathrm{~mm}$, where Alfisols persist on mafic parent materials alongside Ultisols on felsic parent materials (Markewich et al. 1990). In tropical Kenya, with much higher evapotranspiration, base saturation of $<35 \%$ is mainly found in soils of regions receiving $>1700 \mathrm{~mm}$ mean annual precipitation (Scott 1962), and this isohyet effectively outlines the low-fertility forest soils (Acrisols, Nitosols, and Ferralsols of Sombroek et al. 1982).

Several other proxies of base saturation useful for paleosol classification have been suggested by Nettleton et al. $(1998,2000)$, who found a relationship between weatherable minerals $(W$ as percent of silt and sand) and base saturation ( $C$ as percent of total cations) of

$$
W=0.284 C+7.1
$$


Table 3. Comparison of Mean Annual Precipitation (MAP), Mean Annual Temperature (MAT), Chemical Index of Alteration without Potassium (CIA-K), and the Molecular Ratio of Bases/Alumina (B/Al) for Alfisols, Mollisols, and Ultisols of North America

\begin{tabular}{lrrrr}
\hline Soil type & MAP $\sigma$ & MAT $\sigma$ & CIA-K $\sigma$ & B/Al $\sigma$ \\
\hline Alfisol $(n=27)$ & $991 \pm 196$ & $11.1 \pm 3.6$ & $69.1 \pm 8.1$ & $.61 \pm .19$ \\
Mollisol $(n=30)$ & $582 \pm 181$ & $9.4 \pm 3.6$ & $51.4 \pm 16.1$ & $1.38 \pm .9$ \\
Ultisol $(n=51)$ & $1239 \pm 138$ & $16.2 \pm 2.5$ & $87.4 \pm$ & 8.9 \\
\hline
\end{tabular}

with low accuracy $\left(R^{2}=0.27, n=258\right)$. The proportion of weatherable minerals needed for an Alfisol using this relationship is at least $15 \%$ in very fine sand or coarse silt fractions.

\section{Dust and Rejuvenation}

Perhaps the biggest surprise of this study is that robust relationships could emerge from such varied parent materials and times for formation. These are such strong controls on soil formation that one would expect uncorrelated scatter plots of geochemical compositions and soil forming variables. A variety of processes are rejuvenating and homogenizing North American soils. Volcanic ash and eolian dust are the primary agents of renewal in North American soil formation (Brimhall et al. 1988; McFadden et al. 1991), especially the voluminous Mount St. Helens and Mazama ashes of the American West (Busacca et al. 1992) and the Wisconsinan loess and till of the Midwest and northeastern United States (Ruhe 1984; Šibrava et al. 1986). Bedrock soils near glacial ice margins are commonly scraped clean by glacial advances and, even where never glaciated, may have been deeply fractured and renewed by frost cracking (Ciolkosz et al. 1990). Many paleokarst terranes on Paleozoic limestones have been renewed by slope wash from surrounding sandstone and siltstone as well as from dustings of postglacial loess (Ruhe and Olson 1980). Even in humid, warm bedrock terraces of the southeastern United States remote from glacier termini and loess, downward weathering into fresh rock provides an upper limit to soil age of about 3 million years (Markewich et al. 1989). Soil formation includes much alteration of minerals in place, but soils are homogenized continent-wide by influxes of eolian dust and volcanic ash, by frost cracking and glacial scouring, and by continued downward weathering.

Another surprise is that the best relationships emerged from subsurface (Bw or $\mathrm{Bt}$ ) horizon composition rather than surface $(\mathrm{A})$ or $\operatorname{deep}(\mathrm{C})$ horizons or profile depth function parameters. This also can be seen as a validation of eolian models of soil building (Brimhall et al. 1988; McFadden et al.
1991), in which B horizon material tends to be of a geological age (some $10^{3}-10^{5} \mathrm{yr}$ ), older than material still accumulating at the surface and younger than materials deeper in the profile that in some cases remains from geologically much earlier periods of weathering. The $\mathrm{B}$ horizon can be considered to have a mean residence time that averages out short-term surficial disruptions and additions as well as deeper residual accumulation.

Less surprising is the emergence of taxonomically relevant geochemical criteria from our data because the Alfisol-Ultisol division was first designed to apply to North American soils (Arnold 1994). Nevertheless, temporal and lithological dependence of United States soil orders is notable in our data (tables 1, 2). In general, Ultisols are found on old landscapes and felsic, noncalcareous parent materials like those of the southeastern United States (Markewich et al. 1989, 1990), but Alfisols occur on young landscapes and mafic, calcareous parent materials like those of the midwestern United States (Ruhe 1984; Holliday 1990). There are exceptions that reflect individual soil histories. Unlike climofunctions in which competing factors are minimized, soil taxonomic criteria reflect the current condition of the soil as a compromise of interacting factors.

\section{Application of Transfer Functions to Eocene and Oligocene Paleosols of Oregon}

Central Oregon has thick sequences of nonmarine volcaniclastic sedimentary rocks, which include many hundreds of paleosols ranging in geological age back to the Paleocene. These rocks have long been famous for their terrestrial fossils, which have been important for understanding the evolution of plants and mammals through the past 45 million years, particularly the well-known evolution of horses (Retallack et al. 1996). The plant fossils provide much information on paleoclimate, by virtue of their botanical affinities and foliar physiognomy (Leopold et al. 1992; Manchester 1994; Meyer and Manchester 1997). Using such well-known climofunctions as depth to calcic horizon as a guide to paleoprecipitation (Retallack 1994), we can add in- 


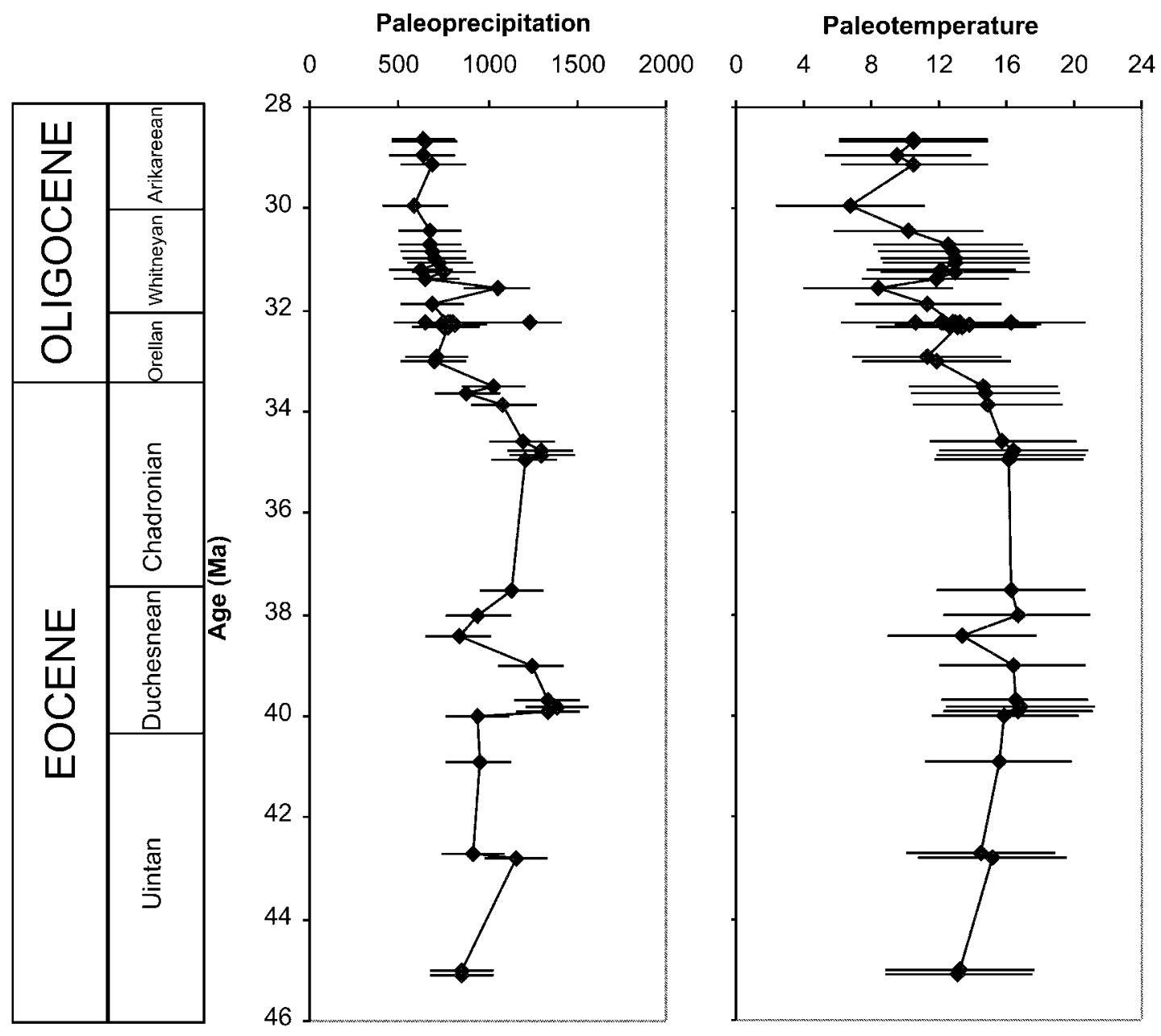

Figure 5. Estimated paleoprecipitation and paleotemperature from a sequence of Eocene and Oligocene paleosols in central Oregon (data from Retallack et al. 2000). Error bars are from calculated standard error and represent \pm 182 $\mathrm{mm}$ and $\pm 4.4^{\circ} \mathrm{C}$

formation from paleosols to this paleontological record (Retallack et al. 2000). These paleosols provide a good test of the climofunctions identified here (figs. 1, 2) because paleoclimatic variation predicted by these climofunctions can be compared with other paleoclimatic proxies from fossil soils and plants.

There are now measured sections and chemical data available for paleosols in the Clarno Formation of middle to late Eocene age (45-39 Ma) in the Clarno area and in the lower John Day Formation of the Painted Hills of late Eocene to Oligocene age (37-28 Ma) in central Oregon (Retallack et al. 2000). These formations represent volcanic back-arc lowland deposits of lakes, streams, and mudflows, including many paleosols. Geological dating in these sequences is supported by numerous high-precision
${ }^{39} \mathrm{Ar} /{ }^{40} \mathrm{Ar}$ single-crystal laser-fusion radiometric dates (Retallack et al. 1996; Bestland et al. 1997, 1999) and from biostratigraphy of mammal fossils (Uintan-Arikareean of fig. 5; Prothero 1998).

The climofunctions presented here (figs. 1, 2, 4) can be applied to Bt horizons of these paleosols (fig. 5) and show a significant climatic break at the Eocene-Oligocene boundary (33.7 Ma), when conditions became both cooler and drier than before. Climate was evidently wet and warm $(>1000 \mathrm{~mm}$ and $>12^{\circ} \mathrm{C}$ ) with some cooler and drier spells during the Eocene. During the Oligocene, however, rainfall fluctuated between about 600 and $800 \mathrm{~mm}$, and mean annual temperatures between $5^{\circ}-12^{\circ} \mathrm{C}$ (fig. 5).

Paleoprecipitation estimates for central Oregon paleosols from chemical data presented here (fig. 5) are strikingly confirmed by paleoprecipitation es- 
timates from depth to calcic horizon in the same paleosols (fig. 6). This is a very close correspondence between several very different paleoclimatic proxies derived from paleosols.

Also confirmed are paleoclimatic indications from fossil plants. Warm, humid conditions for middle Eocene floras of this region are indicated by high specific diversity, abundant vines, tropical taxa such as palms (Sabalites) and Magnolia, and large, entire-margined leaves with drip tips. Manchester (1994) proposed a mean annual temperature of $20^{\circ}-25^{\circ} \mathrm{C}$ and a humid rainfall regime during the middle Eocene for central Oregon. Leopold et al. (1992) suggested late Eocene "woody savanna" conditions, implying 900-1500 mm mean annual precipitation for much of the intermontane West, with substantial drying in the early Oligocene. Cool temperate humid conditions are apparent from early Oligocene floras of the region because of their lower diversity, deciduous taxa such as oaks (Quercus) and elms (Ulmus), and smaller leaves with dentate margins. Meyer and Manchester (1997) propose a mean annual temperature of $3^{\circ}-11^{\circ} \mathrm{C}$ for the early Oligocene (32 Ma). These and other estimates (Wolfe 1995) are all quite close to those from the transfer functions outlined here and give confidence in their utility for paleoclimatic reconstruction from paleosols.

\section{Conclusions}

Our analysis of chemical data on 126 representative North American soils from the last national survey of soil bulk chemical composition (Marbut 1935) has shown at least four robust climofunctions between the chemical index of alteration without $\mathrm{K}$ and mean annual precipitation (fig. 1), the molecular ratio of base/alumina in the $\mathrm{B}$ horizon and mean annual precipitation (fig. 2), between the molecular ratio of lime to alumina in Mollisols and mean annual precipitation (fig. 3), and between the soda and potash to alumina ratio and mean annual temperature (fig. 4). Many other relationships were explored and found to be of little statistical significance. The fact that any reasonable climofunction relationship should emerge from soils of such disparate vegetation, parent materials, topographic setting, and time for formation is surprising but also encouraging. The relationships that we have uncovered are robust enough to be applied to many paleosols but are not unlimited in their applicabil-

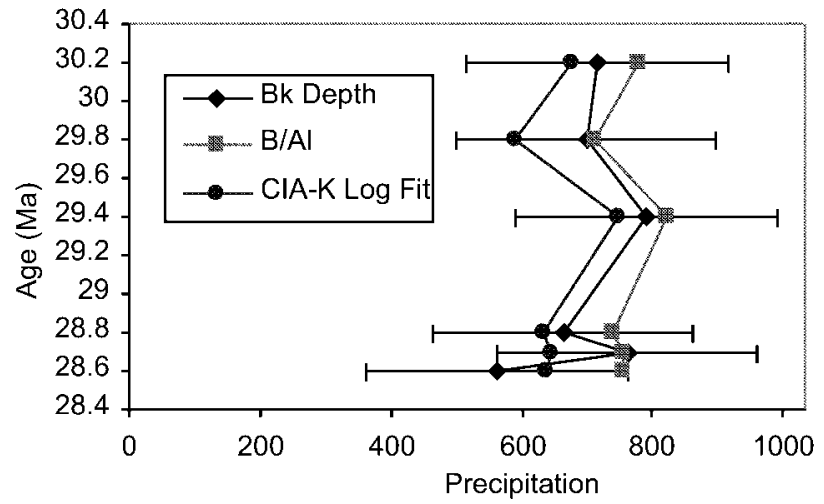

Figure 6. Comparison of paleoprecipitation estimates from multiple proxies from Late Oligocene paleosols of central Oregon (data from Retallack et al. 2000). Our new paleoprecipitation estimates fall within $1 \mathrm{SD}( \pm 141 \mathrm{~mm})$ of paleoprecipitation estimates from depth to the Bk horizon in contemporaneous paleosols.

ity to soils of swamps, deserts, or deeply weathered tropical regions.

An implication of the muted effect of differences in soil age and parent material in compromising our climofunctions is that volcanic ash and eolian dust plays a role in homogenizing the chemical composition of soil Bt horizons in North America (McFadden et al. 1991). Although the equations we have derived are not as precise as we would like, they are adequate for some applications, such as the paleoclimatic interpretation of paleosols. We found that estimates of paleoprecipitation and paleotemperature from chemical data using the equations presented here gave results consistent with other paleopedological (Retallack et al. 2000) and paleobotanical (Manchester 1994; Meyer and Manchester 1997) evidence from fossiliferous paleosols ranging in age from 45-28 million years old in central Oregon.

\section{A C K N O W LED G M E N T S}

We thank B. Tegge and D. Ready, who revealed the initial promise of this approach. G. J. Retallack was funded by the National Parks Service, and both N. D. Sheldon and G. J. Retallack were funded by National Science Foundation grant EAR-0000953 for work on paleosols in central Oregon. We also thank S. Driese for a helpful review. 


\section{R E F E R E N C E S C I T E D}

Arnold, R. W. 1994. Soil geography and factor functionality: interacting concepts. In Amundson, R.; Harden, T.; and Singer, M., eds. Factors of soil formation-a fiftieth anniversary retrospective. Soil Sci. Soc. Am. Spec. Publ. 33:99-109.

Barrientos, X., and Selverstone, J. 1987. Metamorphosed soils as stratigraphic indicators in deformed terranes: an example from the eastern Alps. Geology 15: 841-844.

Bestland, E. A.; Hammond, P. E.; Blackwell, D. L. S.; Retallack, G. J.; and Stimac, J. 1999. Geologic framework of the Clarno Unit, John Day Fossil Beds National Monument, central Oregon. Oreg. Geol. 61:3-19.

Bestland, E. A.; Retallack, G. J.; and Swisher, C. C. 1997. Stepwise climate change recorded in Eocene-Oligocene paleosol sequences from central Oregon. J. Geol. 105:153-172.

Bockheim, J. G. 1997. Properties and classification of cold desert soils from Antarctica. Soil Sci. Soc. Am. J. 61: 224-231.

Brimhall, G. H.; Lewis, C. J.; Ague, J. J.; Dietrich, W. E.; Hampel, J.; Teague, T.; and Rix, P. 1988. Metal enrichment in bauxites by deposition of chemically mature aeolian dust. Nature 333:819-824.

Busacca, A. J.; Nelstead, K. T.; McDonald, E. V.; and Purser, M. D. 1992. Correlation of distal tephra layers in loess in the Channeled Scabland and Palouse of Washington State. Quat. Res. 37:281-303.

Ciolkosz, E. J.; Carter, B. J.; Hoover, M. T.; Cronce, R. C.; Waltman, W. J.; and Dobos, R. R. 1990. Genesis of soils and landscapes in the Ridge and Valley Province of central Pennsylvania. Geomorphology 3:245-261.

Donkin, M. J., and Fey, M. V. 1993. Relationships between soil properties and climatic indices in southern Natal. Geoderma 59:197-212.

Folkoff, M. E. 1987. Climatic control of soil acidity in the B horizon of United States soils. Phys. Geogr. 8: 82-97.

Hare, F. K., and Thomas, M. K. 1974. Climate Canada. Toronto, Wiley of Canada, $256 \mathrm{p}$.

Holliday, V. T. 1990. Soils and landscape evolution of eolian plains: the southern High Plains of Texas and New Mexico. Geomorphology 3:489-515.

Jenny, H. J. 1941. Factors in soil formation. New York, McGraw-Hill.

Leopold, A. B.; Liu, G.-W.; and Clay-Poole, S. 1992. Low biomass vegetation in the Oligocene? In Prothero, D. R., and Berggren, W. A., eds. Eocene-Oligocene climatic and biotic evolution. Princeton, N.J., Princeton University Press, p. 399-420.

Manchester, S. R. 1994. Fruits and seeds of the middle Eocene nut beds flora, Clarno Formation, Oregon. Palaeontogr. Am. 58:1-205.

Marbut, C. F. 1935. Atlas of American agriculture. III. Soils of the United States. Washington, D.C., Government Printing Office.
Markewich, H. W.; Pavich, M. J.; and Buell, G. R. 1990. Contrasting soils and landscapes of the Piedmont and Coastal Plain, eastern United States. In McFadden, L. D., and Kneupfer, P. L. K., eds. Soils and landscape evolution. Geomorphology 3:417-447.

Markewich, H. W.; Pavich, M. J.; Mausbach, M. J.; Hall, R. L.; Johnson, R. G.; and Hearn, P. P. 1989. Age relations between soils and geology of the coastal plain of Maryland and Virginia. U.S. Geol. Surv. Bull. 1589A:1-34.

Maynard, J. B. 1992. Chemistry of modern soils as a guide to interpreting Precambrian paleosols. J. Geol. 100: 279-289.

McFadden, L. D.; Amundson, R. G.; and Chadwick, O. A. 1991. Numerical modeling, chemical, and isotopic studies of carbonate accumulation in soils of arid regions. In Nettleton, W. D., ed. Occurrence, characteristics, and genesis of carbonate, gypsum and silica accumulations in soils. Soil Sci. Soc. Am. Spec. Publ. 26:17-35.

McIntosh, P. D.; Lee, W. D.; and Banks, T. 1983. Soil development and vegetation trends along a rainfall gradient on the East Otago uplands. N. Z. J. Sci. 26: 379-401.

Meyer, H. W., and Manchester, S. R. 1997. The Oligocene Bridge Creek flora of the John Day Formation, Oregon. Univ. Calif. Publ. Geol. Sci. 141:1-195.

Mora, C. I.; Sheldon, B. T.; Elliott, W. C.; and Driese, S. G. 1998. An oxygen isotope study of illite and calcite in three Appalachian vertic paleosols. J. Sediment. Res. A68:456-464.

Nesbitt, H. W., and Young, G. M. 1982. Early Proterozoic climates and plate motions inferred from major element chemistry of lutites. Nature 299:715-717.

Nettleton, W. D.; Brasher, B. R.; Benham, E. L.; and Ahrens, R. J. 1998. A classification system for buried paleosols. In Follmer, L. R.; Johnson, D. L.; and Catt, J. A., eds. Revisitation of concepts in paleopedology: transactions of the Second International Symposium on Paleopedology. Quat. Int. 51/52:175-183.

Nettleton, W. D.; Olson, C. G.; and Wysocki, D. A. 2000. Paleosol classification: problems and solutions. Catena 41:61-69.

Ollier, C., and Pain, C. 1996. Regolith, soils and landforms. Chichester, Wiley.

Prothero, D. R. 1998. The chronological, climatic and paleogeographic background to North American mammalian evolution. In Janis, C. M.; Scott, K. M.; and Jacobs, L. L., eds. Evolution of Tertiary mammals of North America. 1. Terrestrial carnivores, ungulates and ungulatelike mammals. Cambridge, Cambridge University Press, p. 1-36.

Ready, C. D., and Retallack, G. J. 1995. Chemical composition as a guide to paleoclimate of paleosols. Geol. Soc. Am. Abstr. 27:A237.

Retallack, G. J. 1991. Untangling the effects of burial 
alteration and ancient soil formation. Annu. Rev. Earth Planet. Sci. 19:183-206.

1994. The environmental factor approach to the interpretation of paleosols. In Amundson, R.; Harden, J.; and Singer, M., eds. Factors of soil formation-a fiftieth anniversary retrospective. Soil Sci. Soc. Am. Spec. Publ. 33:31-64.

. 1997. A colour guide to paleosols. Chichester, Wiley, $175 \mathrm{p}$.

- 2000. Depth to pedogenic carbonate horizon as a paleoprecipitation indicator? comment and reply. Geology 28:572-573.

- 2001a. Cenozoic expansion of grasslands and climatic cooling. J. Geol. 109:407-426.

. $2001 \mathrm{~b}$. Soils of the past: an introduction to paleopedology ( $2 \mathrm{~d}$ ed.). Oxford, Blackwell Science, $404 \mathrm{p}$.

Retallack, G. J.; Bestland, E. A.; and Fremd, T. J. 1996. Reconstructions of Eocene and Oligocene plants and animals of central Oregon. Oreg. Geol. 58:51-69.

2000. Eocene and Oligocene paleosols of central Oregon. Geol. Soc. Am. Spec. Pap. 344:1-192.

Royer, D. L. 1999. Depth to pedogenic carbonate horizon as a paleoprecipitation indicator? Geology 27: 1123-1126.

Ruffner, J. H. 1980. Climates of the states (3d ed.). Detroit, Gale Research.

Ruhe, R. V. 1984. Soil climate system across the prairies of midwestern USA. Geoderma 34:201-219.
Ruhe, R. V., and Olson, C. G. 1980. The origin of terra rossa in the karst of southern Indiana. In Shaver, R., ed. Field trips 1980 from the Indiana University campus, Bloomington. Bloomington, Ind., Department of Geology, Indiana University, p. 84-122.

Scott, R. M. 1962. Exchangeable bases of mature, welldrained soils in relation to rainfall in East Africa. J. Soil Sci. 13:1-9.

Sheldon, N. D., and Retallack, G. J. 2001. Equation for compaction of paleosols due to burial. Geology 29: 247-250.

Šibrava, V.; Bowen, D. Q.; and Richmond, G. H., eds. 1986. Quaternary glaciations in the Northern Hemisphere. Quat. Sci. Rev. 5:1-510.

Soil Survey Staff. 1998. Keys to soil taxonomy. Blacksburg, Va., Pocahontas.

Sombroek, W. G.; Braun, H. M. H.; and van der Pouw, B. J. A. 1982. Exploratory soil map and agroclimatic zone map of Kenya, 1980. Nairobi, Kenya Soil Survey, scale $1: 1,000,000$.

Tegge, B. J. 1986. A preliminary study of the relationships between precipitation and the abundance and distribution of potassium within selected Unites States soils. Proc. Oreg. Acad. Sci. 22:35.

Washburn, A. L. 1980. Geocryology. New York, Wiley.

Wolfe, J. A. 1995. Paleoclimatic estimates from Tertiary leaf assemblages. Annu. Rev. Earth Planet. Sci. 23: 119-143. 
Copyright $\odot 2002$ EBSCO Publishing 